POETRY UNBOUND 



\title{
Poetry Unbound
}

\author{
POEMS AND NEW MEDIA FROM
}

THE MAGIC LANTERN TO INSTAGRAM

Mike Chasar

Columbia University Press

New York 


\author{
Columbia University Press \\ Publishers Since 1893 \\ New York Chichester, West Sussex \\ cup.columbia.edu \\ Copyright $\odot 2020$ Columbia University Press \\ All rights reserved
}

Cataloging-in-Publication Data available from the Library of Congress.

ISBN 978-0-231-18894-4 (cloth)

ISBN 978-0-231-18895-1 (paperback)

ISBN 978-0-231-54808-3 (ebook)

LCCN 2019037617

Columbia University Press books are printed on permanent and durable acid-free paper.

Printed in the United States of America

Cover design: Noah Arlow 
Even whilst we speak

New notes arise.

-PERCY BYSSHE SHELLEY, PROMETHEUS UNBOUND 
